\title{
Genotoxic activity of the insecticide Nuvacron (Monocrotophos) detected by the micronucleus test in bone marrow erythrocytes of mice and in $\mathrm{CHO}$ cells
}

\author{
Paulo Peitl Jr. ${ }^{1,2}$, Elza T. Sakamoto-Hojo ${ }^{2,3}$ and Ilce M. de Syllos Cólus ${ }^{1}$
}

\begin{abstract}
The organophosphorus insecticide Nuvacron (Monocrotophos) is a very toxic agent widely utilized in Brazilian agriculture. To evaluate the clastogenic potential of this insecticide, in vivo and in vitro micronucleus $(\mathrm{MN})$ assay experiments were carried out on Swiss mice and on Chinese hamster ovary (CHO) cells, respectively. Nuvacron administered at doses of 2.5 and $5.0 \mathrm{mg} / \mathrm{kg}$ induced a statistically significant increase in the frequencies of $\mathrm{MN}$ detected in polychromatic bone marrow erythrocytes from animals (six/group) treated ip $24 \mathrm{~h}$ before. Exponentially growing CHO cells were treated continuously (16 h) with Nuvacron diluted in water to final concentrations of $1,10,100,200$, and $400 \mu \mathrm{g} / \mathrm{ml}$. Three experiments were carried out using the cytokinesis-block method and a total of 6000 binucleated cells were scored to determine MN frequencies. A statistically significant increase in the frequencies of $\mathrm{MN}$ was observed for the cells treated with 1 and $10 \mu \mathrm{g} / \mathrm{ml}$ Nuvacron. A marked decrease in cell proliferation rates was observed for CHO cultures treated with higher concentrations. These data demonstrate that Nuvacron has a genotoxic effect on both in vivo and in vitro mammalian test systems.
\end{abstract}

\section{INTRODUCTION}

Many different types of pesticides have been introduced on the market in order to increase the production of food-stuffs. In addition to the direct occupational exposure of workers during the formulation, manipulation and application of pesticides, the human

\footnotetext{
${ }^{1}$ Departamento de Biologia Geral, Universidade Estadual de Londrina, Caixa Postal 6001, 86051-970 Londrina, PR, Brasil.

2 Departamento de Genética e Matemática Aplicada à Biologia, Faculdade de Medicina de Ribeirão Preto, Universidade de São Paulo, 14049-900 Ribeirão Preto, SP, Brasil.

${ }^{3}$ Departamento de Biologia, Faculdade de Filosofia, Ciências e Letras de Ribeirão Preto, Universidade de São Paulo, Av. Bandeirantes 3900, 14040-901 Ribeirão Preto, SP, Brasil. Send correspondence to E.T.S.-H.
}

population is also exposed to them indirectly due to the persistence of their residues in the soil and in animal and plant tissues (Grover and Malhi, 1985).

Several methods are available to determine the genotoxic effects of chemicals. The micronucleus (MN) test, described by Schmid (1975), can detect mutagenic substances in mammals by revealing compounds that cause chromosome breaks or interfere with the mitotic spindle. MN can also be detected in fibroblast cell cultures using the cytokinesis-block method with cytochalasin B (Cyt-B). This process gives rise to binucleated cells with individualized nuclei, clearly showing that these cells only underwent one mitotic division, thus permitting $\mathrm{MN}$ analysis in first cycle cells (Fenech and Morley, 1985). 
The mutagenic potential of organophosphorus pesticides has been investigated in many laboratories (Niraj and Patnaik, 1992) and there is a considerable body of evidence showing the ability of these insecticides to induce chromosome damage (Adhikari and Grover, 1988), sister chromatid exchange (Sobti et al. 1982) or point mutations (Moriya et al. 1983). Their genotoxic properties have been observed in plant systems in which the product induced several structural chromosome alterations in root tip cells (De Kergommeaux et al., 1983; Devadas et al., 1987).

Cytogenetic studies on Chinese hamster ovary ( $\mathrm{CHO})$ cells have indicated that Monocrotophos induces significant levels of chromosome exchanges (Lin et al., 1987). Vaidya and Patankar (1982) have also observed altered levels of chromosome aberrations in human lymphocyte cultures. Shandhu et al. (1985) observed that Monocrotophos causes gene mutations in bacteria and DNA damage in human lung cells in culture. In vivo studies on chicken bone marrow cells and blood erythrocytes have also revealed the clastogenic action of this product (Bhunya and Jena, 1993).

The objective of the present study was to detect the genotoxic effects of Nuvacron (Monocrotophos) by applying the micronucleus test to bone marrow cells of mice and $\mathrm{CHO}$ cells in culture.

\section{MATERIAL AND METHODS}

\section{Chemical agent}

The organophosphorus insecticide Monocrotophos [(cis-2-methyl carbamoyl 1 methyl vinyl) dimethyl phosphate], commercially sold as Nuvacron-400, is manufactured by Ciba-Geigy Química S/A (Brazil). This product has been assigned to toxicological class I (highly toxic) and has the following structural formula:

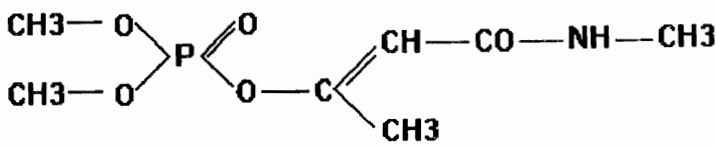

The product used in our experiments is commercially sold in agricultural goods stores. This pesticide contains $400 \mathrm{~g} / 1$ of the active principle Monocrotophos in non-aqueous concentrated solution, $\mathrm{pH}$ 1.5. The acute oral $\mathrm{LD}_{50}$ dose for rats is $14-23 \mathrm{mg} / \mathrm{kg}$ and the dermal dose is $333 \mathrm{mg} / \mathrm{kg}$ (Ciba-Geigy technical guide).

\section{Micronucleus test in bone marrow erythrocytes of mice}

Male and female Swiss mice (Mus musculus) weighing approximately $30 \mathrm{~g}$ were maintained in polyethylene boxes with a wire lid of the type normally used in the laboratory, with food and water ad libitum. Experimental and control groups composed of six animals each were used. On the basis of the oral $\mathrm{LD}_{50}$ in rats we carried out pilot experiments for the determination of the concentrations to be used. The 10 $\mathrm{mg} / \mathrm{kg}$ concentration proved to be highly toxic to the animals and the intraperitoneal $\mathrm{LD}_{50}$ was observed at a dose of $7.0 \mathrm{mg} / \mathrm{kg}$. On the basis of these results, Nuvacron was diluted in distilled water and single doses of $1.25,2.5$ and $5.0 \mathrm{mg} / \mathrm{kg}$ body weight $(70 \%$ of the $L_{50}$ ) were administered to the animals intraperitoneally. Cyclophosphamide (Sigma) was used as a positive control at $8 \mathrm{mg} / \mathrm{kg}$ body weight, and distilled water was used as a negative control. The animals were sacrificed by ether inhalation $24 \mathrm{~h}$ after treatment.

Bone marrow cells for $\mathrm{MN}$ analysis were obtained by the technique of Schmid (1975). The slides were prepared with fine smears of the material and after $24 \mathrm{~h}$ the cells were fixed with absolute methanol for 10 min. The air-dried preparations were stained with Giemsa diluted in phosphate buffer (1:10) for $10 \mathrm{~min}$. One thousand cells per animal were analyzed for the presence of $\mathrm{MN}$ in polychromatic erythrocytes (PCEs), for a total of 6000 cells per treatment. The frequencies of $\mathrm{MN}$ were determined as the number of MN per 1000 micronucleated PCEs.

\section{Micronucleus test in $\mathrm{CHO}$ cells}

$\mathrm{CHO}$ cells $\left(\mathrm{CHO}_{9}\right.$ line $)$ were kindly provided by Prof. Dr. A.T. Natarajan (University of Leiden, Holland). The cells were grown in HAM F10 (Sigma) + DEM (Sigma) (1:1) supplemented with $10 \%$ fetal calf serum (Cultilab), $2.38 \mathrm{mg} / \mathrm{ml}$ Hepes (Sigma), plus 0.01 $\mathrm{mg} / \mathrm{ml}$ streptomycin and $0.005 \mathrm{mg} / \mathrm{ml}$ penicillin. Cells were cultured at $37^{\circ} \mathrm{C}$ as a monolayer in $5 \mathrm{ml}$ culture medium using disposable $25-\mathrm{cm}^{2}$ flasks (Corning). As a routine, the cells were subcultured every $72 \mathrm{~h}$ when they reached a state of semi-confluence. A solution of $0.2 \%$ trypsin plus $0.02 \%$ versene was used to detach the cells from the inner surface of the flask. In each experiment, $1 \times 10^{6}$ cells were plated onto each culture flask, and after $1 \mathrm{~h}$ the cells were treated with the insecticide. Based on the study by Lin et al. (1987), who employed concentrations of $800,400,200,100$ and $50 \mu \mathrm{g} / \mathrm{ml}$ to test the clastogenicity of Monocrotophos, by analysis of 
chromosome aberrations in $\mathrm{CHO}$ cells, we performed pilot tests to determine the concentrations to be used. Since concentrations higher than $800 \mu \mathrm{g} / \mathrm{ml}$ proved to be highly cytotoxic, we established the concentrations of $1,10,100,200$ and $400 \mu \mathrm{g} / \mathrm{ml}$ culture medium as the test doses. The cells were incubated for $16 \mathrm{~h}$ at $37^{\circ} \mathrm{C}$ in the presence of $3 \mu \mathrm{g} / \mathrm{ml} \mathrm{Cyt-B}$ in order to obtain binucleated cells, as with the cytokinesis-block method for human lymphocytes (Fenech and Morley, 1985). The antitumoral alkaloid ellipticine (EPC) (Sigma) was used as a positive control, at a final concentration of $3 \mu \mathrm{g} / \mathrm{ml}$ culture medium in 30 -min pulse treatment. The preparations were fixed with methanol/acetic (3:1) and stained with Giemsa diluted in phosphate buffer for 10 min. Two thousand binucleate cells per culture were analyzed in each experiment, for a total of 6000 cells per treatment, and the presence of binucleated cells with micronuclei was recorded.

To verify whether Nuvacron can induce any effect on the kinetics of the cell cycle, we calculated the cell proliferation rate (CPR) by analyzing the frequencies of mono-, bi-, tri- and tetranucleated cells for different treatments, according to the following formula: $\mathrm{CPR}=(1 \times$ frequency of mononucleated cells $)$ $+(2 x$ frequency of binucleated cells $)+(3 x$ frequency of tri- or tetranucleated cells) (Hoffmann et al., 1994).

\section{RESULTS}

The results obtained in the in vivo test system are presented in Table I. It can be seen that the animals treated with an aqueous solution of Nuvacron at doses of 2.5 and $5.0 \mathrm{mg} / \mathrm{kg}$ body weight presented the highest frequencies of $\mathrm{MN}$ scored in PCE. The data for the experimental and negative control groups were analyzed statistically by the exact Fisher test, and the differences were shown to be significant $(P<0.05)$,

Table I - Frequencies of micronucleus (MN) in polychromatic erythrocytes (PCE) observed in Swiss mice treated $i p$ with different doses of Nuvacron. The animals were sacrificed $24 \mathrm{~h}$ after treatment.

\begin{tabular}{|c|c|c|c|c|c|c|c|c|}
\hline \multirow[t]{3}{*}{ Treatment } & \multirow{3}{*}{$\begin{array}{c}\text { Dose } \\
\mathrm{mg} / \mathrm{kg} \\
\text { body weight }\end{array}$} & \multicolumn{6}{|c|}{$\begin{array}{c}\text { Number of MN per } 1000 \\
\text { PCE/animal }\end{array}$} & \multirow[t]{3}{*}{$\begin{array}{c}\text { Mean } \\
\text { (\%) MNPCE }\end{array}$} \\
\hline & & \multicolumn{6}{|c|}{ Animal } & \\
\hline & & $\mathrm{A}$ & B & $\mathrm{C}$ & $\mathrm{D}$ & $\mathrm{E}$ & $\mathrm{F}$ & \\
\hline Control (water) & 0.0 & 3 & 3 & 2 & 0 & 3 & 3 & $(0.23)$ \\
\hline Cyclophosphamide & 8.0 & 17 & 11 & 12 & 11 & 12 & 9 & $(1.20)^{*}$ \\
\hline Nuvacron & 1.25 & 3 & 2 & 3 & 2 & 1 & 2 & $(0.21)$ \\
\hline Nuvacron & 2.5 & 6 & 7 & 6 & 8 & 8 & 7 & $(0.70)^{*}$ \\
\hline Nuvacron & 5.0 & 8 & 6 & 8 & 6 & 4 & 6 & $(0.63)^{*}$ \\
\hline
\end{tabular}

$* \mathrm{P}<0.05$ compared to controls (exact Fisher test). indicating clastogenic action of Nuvacron at high concentrations.

Table II presents the total number of binucleated $\mathrm{CHO}$ cells with micronuclei observed in the different treatments with Nuvacron, compared to the control. The highest percentages of MN scored in binucleated cells were obtained at the lowest concentrations. When the data were submitted to the exact Fisher test, the cultures treated with 1.0 and $10 \mu \mathrm{g} / \mathrm{ml}$ Nuvacron presented significantly higher values $(P<0.05)$. At these concentration levels, the cell proliferation indices were constant but they showed reduction at concentrations higher than $10 \mu \mathrm{g} / \mathrm{ml}$ (Table III). In both assays, the chemicals used as positive controls were very efficient at inducing chromosome damage, agreeing with reports in the literature (Sakamoto-Hojo et al., 1988; Preston et al., 1987).

\section{DISCUSSION}

The genotoxicity of the organophosphorus insecticide Nuvacron (Monocrotophos) has been demonstrated in several organisms such as Salmonella (Shirasu et al., 1976), E. coli (Moriya et al., 1983), Allium cepa root-tip cells (Rao et al., 1987), rat bone marrow cells (Wang et al., 1987; Grover et al., 1988), CHO cells (Lin et al., 1987), human lymphocytes (Vaidya and Patankar, 1982), and chicken bone marrow cells (Bhunya and Jena, 1993). Monocrotophos was found to have a clastogenic action on all of these test systems, and also on mouse bone marrow cells and $\mathrm{CHO}$ cells in culture, as demonstrated in this study.

The micronucleus test is one of the most efficient methods to detect clastogenic and aneugenic compounds in the environment (Schmid, 1976; Savage, 1988). The evaluation of $\mathrm{MN}$ incidence is important because they have been correlated with the process of tumor initiation (Jayashree et al., 1994).

The in vivo test system showed a significant increase in the frequencies of $\mathrm{MN}$ at concentrations of 2.5 and $5 \mathrm{mg} / \mathrm{kg}$ body weight, compared to the negative control (Table I). These results diverge from those reported by Bhunya and Behera (1958), who observed significant variations for chromosomal aberrations and sperm shape abnormalities, but not for $\mathrm{MN}$ in mice treated ip with Nuvacron. 
Table II - Frequencies of micronucleus (MN) in binucleated Chinese hamster ovary cells after treatment with different concentrations of Nuvacron (NV) in three experiments (E1, E2 and E3).

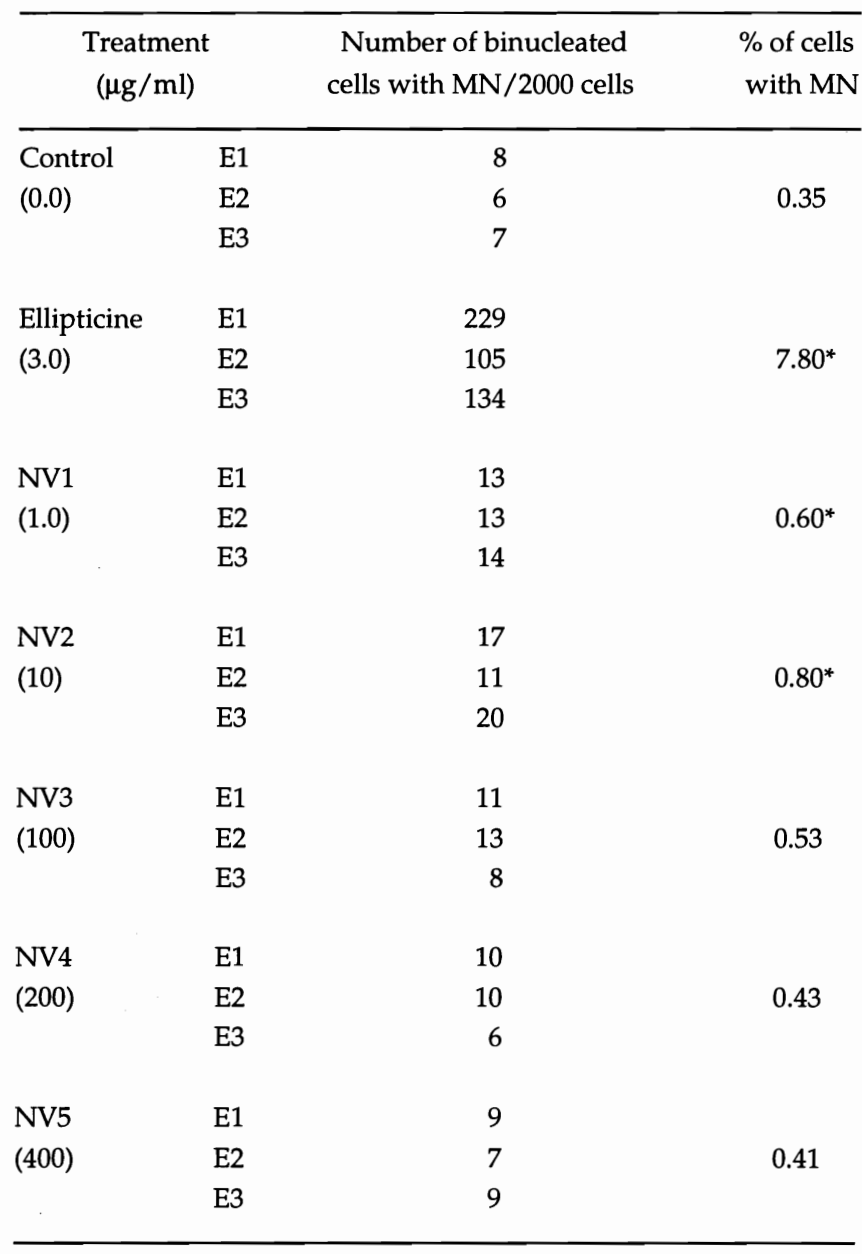

${ }^{*} \mathrm{P}<0.05$ compared to controls (exact Fisher test).

In their study, each animal received two doses of the product, with a 24-h interval, and the bone marrow cells were fixed $6 \mathrm{~h}$ after the last treatment.

According to Cole et al. (1981), induction of MN in mice coincides with the kinetics of the erythropoietic system $(22-24 \mathrm{~h})$. Several studies have shown that maximum expression of $\mathrm{MN}$ in bone marrow cells occurs when the material is collected $24 \mathrm{~h}$ after treatment. This seems to be the ideal time for the clastogen to reach the target cells (erythrocytes) and cause the appearance of MN (Jenssen and Ramel, 1978; Krishna et al., 1991; Jagetia and Ganapathi, 1994; Hayashi et al., 1994).

In the present study, the fact that the animals treated with $5 \mathrm{mg} / \mathrm{kg}$ dose presented lower frequencies of $\mathrm{MN}$ than the animals treated with $2.5 \mathrm{mg} / \mathrm{kg}$ can be explained by the high cytotoxicity induced at the highest concentration.

Our results also indicate the clastogenic potential of Monocrotophos for $\mathrm{CHO}$ cells. Cultures
Table III - Frequencies of mono-, bi-, tri- and tetranucleated cells and cell proliferation rates observed in Chinese hamster ovary cell cultures treated with different Nuvacron concentrations; one thousand cells were analyzed per treatment.

\begin{tabular}{rcccc}
\hline \multirow{2}{*}{$\begin{array}{c}\text { Treatment } \\
(\mu \mathrm{g} / \mathrm{ml})\end{array}$} & $\begin{array}{c}\text { Mononucleated } \\
\text { cells }\end{array}$ & $\begin{array}{c}\text { Binucleated } \\
\text { cells }\end{array}$ & $\begin{array}{c}\text { Tri-and } \\
\text { tetranucleated } \\
\text { cells }\end{array}$ \\
\cline { 2 - 4 } & & & 0.07 & 1.96 \\
\hline 0 & 0.11 & 0.82 & 0.09 & 1.99 \\
1 & 0.10 & 0.81 & 0.07 & 1.97 \\
10 & 0.10 & 0.83 & 0.05 & 1.77 \\
100 & 0.26 & 0.68 & 0.06 & 1.69 \\
200 & 0.29 & 0.61 & 0.07 & 1.64 \\
400 & 0.43 & 0.50 & & \\
\hline
\end{tabular}

CPR: Cell proliferation rate.

treated with low concentrations ( 1 and $10 \mu \mathrm{g} / \mathrm{ml}$ ) showed significantly increased frequencies of $\mathrm{MN}$ compared to the negative control. In the pilot experiments performed, the insecticide proved to be highly cytotoxic to $\mathrm{CHO}$ cells at the concentration of 800 $\mu \mathrm{g} / \mathrm{ml}$, causing a high rate of cell death. This high cytotoxicity may also have been responsible for the lower frequencies of $\mathrm{MN}$ in binucleated cells observed in the treatment with the concentrations of 100,200 and $400 \mu \mathrm{g} / \mathrm{ml}$. In these treatments, the frequencies of cells in the first cycle were higher and there was a reduction in cell proliferation rate compared to the control, suggesting that the insecticide interfered with the kinetics of the cell cycle, causing a delay in the cycle progression. This cytotoxic effect of the insecticide justifies the lower frequencies of $\mathrm{MN}$ observed at high concentrations. This result confirms those reported by Sobti et al. (1982), who stated that several organophosphorus insecticides, among them Azodrin (which also has Monocrotophos as the active principle), can disturb the kinetics of the cell cycle in human lymphocytes cultured in vitro.

The mechanism of action of Monocrotophos at the molecular level is not fully clear. Attention is being focused upon electrophilic reactivity as the fundamental cause of the toxicity of many cytotoxic compounds. DNA alkylation might be one of the reasons for the production of chromosomal aberrations by the organophosphates (Jayashree et al., 1994). The common structural element of these chemicals, i.e., $\mathrm{P}-\mathrm{O}-\mathrm{C}$ with phosphorus and carbon as electrophilic sites, offers the key for understanding the reactions of the organophosphates with nucleophiles. In general, the phosphate group is a good substrate for the nucleophilic attack that causes DNA phosphorylation, inducing chromosome damage (Klopman et al., 1985). 
We conclude that, besides the well-known genotoxicity of Monocrotophos that has been demonstrated since twenty years ago (Niraj and Patnaik, 1992), our results confirm the ability of the product to interact with the genetic material of mammalian cells in vivo and in vitro, causing chromosome damage.

\section{ACKNOWLEDGMENTS}

The authors wish to thank Sueli A. Neves and Luís A. Costa Jr. for valuable technical assistance. Research supported by Conselho Nacional de Desenvolvimento Científico e Tecnológico (CNPq), Fundação de Amparo à Pesquisa do Estado de São Paulo (FAPESP), Universidade Estadual de Londrina (UEL) and Secretaria Estadual de Ciência e Tecnologia do Estado do Paraná/CONCITEC.

Publication supported by FAPESP.

\section{RESUMO}

O inseticida organofosforado Nuvacron (Monocrotophos) é um produto muito tóxico e amplamente utilizado na agricultura brasileira. Para avaliar o potencial clastogênico desse inseticida, foi utilizado o teste do micronúcleo (MN) in vivo em camundongos Swiss e in vitro em células $\mathrm{CHO}$ (células de ovário de hamster chinês). O Nuvacron administrado nas concentrações de 2,5 e 5,0 mg/ kg induziu um aumento estatisticamente significativo nas freqüências de $\mathrm{MNs}$ em eritrócitos policromáticos de medula óssea dos animais tratados intraperitonealmente $24 \mathrm{~h}$ antes. Esses experimentos foram realizados utilizando seis animais por tratamento. Células $\mathrm{CHO}$ em crescimento exponencial receberam tratamento contínuo (16 h) com Nuvacron diluído em água destilada nas concentrações finais de 1, 10, 100, 200 e $400 \mu \mathrm{g} / \mathrm{ml}$. Foram realizados três experimentos utilizando o método de bloqueio da citocinese pela citocalasina-B e um total de 6000 células binucleadas foram analisadas para a determinação das freqüências de MNs. Um aumento estatisticamente significativo nas freqüências de MNs foi observado nas células tratadas com 1 e $10 \mu \mathrm{g} / \mathrm{ml}$ de Nuvacron. Verificou-se também uma queda nos índices de proliferação celular nas culturas de $\mathrm{CHO}$ tratadas com as concentrações mais elevadas, mostrando um efeito citotóxico nesses níveis de concentração, o que justifica a ausência de indução de MNs. Dessa forma podemos concluir que o inseticida Nuvacron apresentou efeito genotóxico nos dois sistemas-teste in vivo e in vitro.

\section{REFERENCES}

Adhikari, N. and Grover, I.S. (1988). Genotoxic effects of some systemic pesticides: In vivo chromosomal aberrations in bone marrow cells in rats. Environ. Mol. Mutagen. 12: 235-242.
Bhunya, S.P. and Behera, B.C. (1988). Mutagenicity assay of an organophosphate pesticide, Monocrotophos in a mammalian in vivo test system. Cytologia 53: 801-807.

Bhunya, S.P. and Jena, G.B. (1993). Studies on the genotoxicity of monocrotophos, an organophosphate insecticide, in the chick in vivo test system. Mutat. Res. 292: 231-239.

Cole, R.J., Taylor, N., Cole, J. and Arlett, C.F. (1981). Short-term tests for transplacentally active carcinogens. Micronucleus formation in fetal and maternal mouse erythroblasts. Mutat. Res. 80: 141-157.

De Kergommeaux, D.J., Grant, W.F. and Sandhy, S.S. (1983). Clastogenic and physiological response of chromosomes to nine pesticides in the Vicia faba in vivo root tip assay system. Mutat. Res. 124: 69-84.

Devadas, N., Sadanandam, A., Kishan, R.R. and Subhash, K. (1987). Induced somatic aberration and chlorophyll mutations in Capsicun by insecticides. Cytologia 52: 235-241.

Fenech, M. and Morley, A.A. (1985). Measurement of micronuclei in lymphocytes. Mutat. Res. 147: 29-36.

Grover, I.S. and Malhi, P.K. (1985). Genotoxic effects of some organophosphorous pesticides. I. Induction of micronuclei in bone marrow cells in rat. Mutat. Res. 155: 131-134.

Grover, I.S., Dhingra, K.A., Adhikari, N. and Ladhar, S.S. (1988). Genotoxicity of pesticides. A comparative study using a battery of assays. Nucleus 31: 69-77.

Hayashi, M., Tice, R.R., MacGregor, J.T., Anderson, D., Blakey, D.H., Kirsh-Volders, M., Oleson, F.B., Pacchierotti, F., Romagna, F., Shimada, H., Sutou, S. and Vannier, B. (1994). In vivo rodent erythrocyte micronucleus assay. Mutat. Res. 312: 293-304.

Hoffmann, G.R., Sayer, A.M. and Littlefield, L.G. (1994). Potentiation of bleomicin by the aminothiol WR-1065 in assays for chromosomal damage in Go human lymphocytes. Mutat. Res. 307: 273-283.

Jagetia, G.C. and Ganapathi, N.G. (1994). Radiation-induced micronucleus formation in mouse bone marrow after low dose exposures. Mutat. Res. 304: 235-242.

Jayashree, I.V., Vijayalaxmi, K.K. and Rahiman, M.A. (1994). The genotoxicity of Hirosan, an organophosphorus pesticide in the in vivo mouse. Mutat. Res. 322: 77-85.

Jenssen, D. and Ramel, C. (1978). Factors affecting the induction of micronuclei at low doses of X-rays, MMS and dimethylnitrosamine in mouse erythroblasts. Mutat. Res. 58: 51-65.

Klopman, G., Contreras, R., Rosenkrans, H.S. and Waters, M.D. (1985). Structure-genotoxicity activity relationship of pesticides. Comparison of the results from several short term assays. Mutat. Res. 147: 343-356.

Krishna, G., Kropko, M.L., Ciaravino, V. and Theiss, J.C. (1991). Simultaneous micronucleus and chromosome aberration assessment in the rat. Mutat. Res. 264: 29-35.

Lin, M.F., Wu, C.L. and Wang, T.C. (1987). Pesticide clastogenicity in Chinese hamster ovary cells. Mutat. Res. 188: 241-250.

Moriya, M., Otha, T., Watanabe, K., Miyazawa, K., Kato, K. and Shirasu, Y. (1983). Further mutagenicity studies on 
pesticides in bacterial reversion assay systems. Mutat. Res. 116: 185-216.

Niraj, K.T. and Patnaik, K.K. (1992). Studies on the genotoxicity of monocrotophos in somatic and germ-line cells of Drosophila. Mutat. Res. 278: 23-29.

Preston, R.J., Dean, B.D., Galloway, S., Holden, H., McFree, A.F. and Shelby, M. (1987). Analysis of chromosome aberrations in bone marrow cells. Mutat. Res. 189: 157165.

Rao, B.U.C.B., Sharma, S.R. and Rao, B.G.S. (1987). Cytological effects of organophosphorus insecticides on Allium cepa root meristems. Cytologia 52: 365-371.

Sakamoto-Hojo, E.T., Takahashi, C.S., Ferrari, I. and Motidome, M. (1988). Clastogenic effect of the plant alkaloid ellipticine on bone marrow cells of Wistar rats and on human peripheral blood lymphocytes. Mutat. Res. 199: 11-19.

Savage, J.R.K. (1988). A comment on the quantitative relationship between micronuclei and chromosomal aberrations. Mutat. Res. 207: 33-36.

Schmid, W. (1975). The micronucleus test. Mutat. Res. 31: 915.

Schmid, W. (1976). The micronucleus test for cytogenetic analysis. In: Chemical Mutagenesis, Principles and Methods for their Detection (Hollaender, A., ed.). Vol. 4. Plenum Press, New York, pp. 31-53.

Shandhu, S.S., Waters, M.D., Simmon, V.F., Mortelmans, K.E., Mitchell, A.D., Jorgenson, T., Jones, D.C.L., Valencia, R. and Stack, F. (1985). Evaluation of the genotoxic potential of certain pesticides used in Pakistan. In: Basic and Applied Mutagenesis (Muhammed, A. and Von Borstel, R.C., eds.). Plenum Press, New York, pp. 185-219.

Shirasu, Y., Moriya, M., Kato, K., Furuhashi, A. and Kada, T. (1976). Mutagenicity screening of pesticides in the microbial system. Mutat. Res. 40: 19-30.

Sobti, R.C., Krishan, A. and Pfaffenberger, C.D. (1982). Cytokinetic and cytogenetic effects of some agricultural chemicals on human lymphoid cells in vitro: organophosphates. Mutat. Res. 102: 89-102.

Vaidya, V.G. and Patankar, N. (1982). Mutagenic effects of monocrotophos, an insecticide, in mammalian test systems. Indian J. Med. Res. 76: 912-917.

Wang, T.C., Lee, T.C., Lin, M.F. and Lin, S.Y. (1987). Induction of sister-chromatid exchanges by pesticides in primary rat tracheal epithelial cells and Chinese hamster ovary cells. Mutat. Res. 188: 311-321.

(Received November 9, 1995) 